\title{
TPM3 wt Allele
}

National Cancer Institute

\section{Source}

National Cancer Institute. TPM3 wt Allele. NCI Thesaurus. Code C97850.

Human TPM3 wild-type allele is located in the vicinity of $1 \mathrm{q} 21.2$ and is approximately 39 $\mathrm{kb}$ in length. This allele, which encodes tropomyosin alpha-3 chain protein, is involved in the mediation of muscle filament movement. Mutation of the gene is associated with nemaline myopathy type 1 and thyroid papillary carcinoma. A chromosomal rearrangement affecting this gene and the NTRK gene is associated with thyroid papillary carcinoma. A chromosomal translocation $\mathrm{t}(1 ; 2)(\mathrm{q} 25 ; \mathrm{p} 23)$ of the gene and the ALK gene is associated with rare cases of both anaplastic large cell lymphoma and inflammatory myofibroblastic tumors. 